des Dramatikers, die Novelle des Epikers erzählt die Tatsachen in ihrer pragmatischen Folge. Im Aufbau der Novelle des Dramatikers erkennen wir die Teile des Dramas wieder, die Exposition, die Steigerung bis zu einem Höhepunkt, die Entwicklung zur Katastrophe. Der Epiker erzählt gelassen die Ereignisse, ohne sie in einen so straffen Aufbau einzuordnen. Diesem inneren Bau entsprechen in der Novelle des Dramatikers geschlossene Szenen und Szenenbilder, die sich hier leichter abgrenzen lassen als in der Novelle des Epikers, wo alles in Fluß ist.

Der Bau der Novelle des Epikers ist mit einer sanft ansteigenden Straße zu vergleichen, auf deren Höhe angelangt, sich uns ein überraschender, aber keineswegs unerwarteter Anblick bietet, da wir allmählich emporsteigend das zu erwartende Bild zum guten Teil schon vorweg genossen haben. Der Bau der dramatischen Novelle führt uns ähnlich wie der des Dramas, wie auf einem kunstvoll angelegten Bergpfade empor, wo wir auf künstlich verborgenen Wegen unversehens in die Höhe gelangen, um plötzlich, auf eine Lichtung hervortretend, einen wundervollen Ausblick in die Ferne zu gewinnen, der aber nur die Vorstufe ist, die Vorbereitung zu einer weit herrlicheren Aussicht, die unser auf dem Gipfel harrt. Beide Wege führen zum Ziel, führen zur Höhe, der eine gemächlich, der andere mit gewaltsameren Mitteln. Durch die Art dieses Weges unterscheidet sich die Novelle des Dramatikers von der des Epikers, ein Unterschied, der also im Grunde auf dem Wesensunterschied des dramatischen und epischen Dichters beruht. Form und Stoff bilden eine Einheit. Der geborene Dramatiker (Stoffdichter), der einen dramatisch nicht verwertbaren Stoff gestaltet und dafür die Form der Novelle wählt, wird eine Novelle mit wesentlich dramatischem Einschlag schaffen. Der geborene Epiker schafft eine Novelle, der dieser dramatische Einschlag fehlt. Es ist kein Zweifel, daß dieses negative Element zugleich eine positive Bestimmung des Wesens der Novelle bildet. Die Novelle des Epikers, also die epische Novelle wird naturgemäß als die Grundform der Novelle bezeichnet werden müssen. Einen positiven Beweis für diese Feststellung bildet ein epischer Dichter wie Gottfried Keller, einen negativen Beweis aber Gerhart Hauptmann mit seinem Bahnwärter Thiel, der in viel höherem Maße der Gattung der Novelle als das gesamte dramatische Lebenswerk Hauptmanns der Gattung des Dramas zugerechnet werden muB.

Weenen.

MAX LEDERER.

\title{
NOTES ON ENGLISH ORTHOGRAPHY (ie and ea).
}

\section{(CONTINUATION).}

VI. Words that in early modern E. had [e] or [ $\varepsilon$ :] followed by $s$ or $s t$.

a. Germanic words.

beast, 'best' :

Letter in Wallace, l. c., p. 153, heaste (twice). geasse, 'guess':

Sir Thomas More 248 G; 281 C, geasse; 1454 D geast ${ }^{1}$ );

1) Grünzinger, l.c., p. 50, where reast is also mentioned as occurring in More's works. 
Udall, Erasm. Par. Matth. XV, $15-20$, ed. 1552 geassed pp. (N.E.D.) geast, 'guest':

Utopia 33, geastwise; Udall, Ralph R. D. p. 11, gueast (: feast). neast:

Respublica V, X, 33; Gascoigne, Compl. Phil. 88; Lyly, Euph. 113, 124; Id. Pappe w. Hatchet, C 11 (N. E. D.); Harvey; El. Ess. 2753.

There are five more instances of neast(s) in the N.E.D., one dating from 1666, and another from 1678, while neasteth is instanced once, neast-egge twice, neastful once, and neastling twice. reast(e):

Ascham, Scholem. 17; Respublica III, IV, 6; III, V, 22; Letters Mun. Room 117/14 1). wreast:

Surrey, Poems l, c., 310/51 wreasteled; Laneham's Letter 53, and Lyly, Euph. 269 wreast; Harvey, El. Ess. II, 251/3 wreasteth.

Laneham has wreast, 'wrist', twice on p. 38.

Stanyhurst has weast, 'west', Aen. 57/7.

b. Romance words.

cheast:

Laneham's Letter 59. creast :

Malory, Arthur V, V (N.E.D.); Bossewell, Title page of Workes of Armorie (N.E.D.); Lyly, Midas V, II (N.E.D.); Cotgrave (N.E.D., creast-risen; creast-style); Camden, Armories (R) (N.E.D.); Spenser, F. Q. I, I, VI (: beast : feast: addrest); I, V, II (: east); III, IV, VII (: beast); III, VI, XXII (: beasts : feasts : beheasts); VI, VI, XII (: beast: least : infest); Id. Ruines of Rome 326 (: beast); Webster, Duch. Malfy IV, II, 92.

deteast:

Spenser, $F . Q$. I, IV, XXI (: feast : beast). ieast, jeast(ing):

Coverdale, Job XXVII, 23; 3 John B/5; Gosson, Sch. of $A b .31$; Grimstone, tr. D' Acosta's Hist. Ind. I, VII, 22; Arden of Fev. IV, IV, 98; Nash, in El. Ess. II, 243/10; Cotgrave, i. v. Bourde (N. E. D.); Shakesp., Rom. and Jal. II, II, 1; Rich. 2, III, II, 77; Twelfth N. II. V, 24. preas:

Rede me 22, prease (:peace); Ibid. 82 prease (:dease, 'table'); Tynd., Mark II, 4; V, 27; Luke V, 19; VIII, 19; XIX, 3; John V, 3, preace; Mark III, 10; Luke V, 1; VI, 19; XXII, 47 preased; Coverdale, Mark III, B/5, preased; Stephen Hawes, Past. of Pl. 59/2 (: cease: increase); 213/3 (: cease); 217/1 (:peace: cease), prease ${ }^{2}$ ); Sir Thomas More XII D prease (: cease); 23 B (prease (: peace) ${ }^{3}$ ); Skelton spells preas consistently 4); Laneham's Letter 41, preas; 6 preast, pret.; Spenser, F. Q. I, III, III,

1) Diehl, l.c., p. 147.

2) Fuhr, l.c., p. 30.

3) Grünzinger, l.c., p. 46.

4) Rudolf, Die engl. Orth. von Caxton bis Shakesp., p. 6. 
II, VII, XLVI preace; I, XII, XIX prease (: peace : release : cease); IV, IV, XXXIV preasse (: ceasse); II, VII, XLIV, preaced (Frequent in Spenser); Sidney, Ps. CLIV, 8 prease; Harrington in El. Ess. II, 218/20 preased, pret.; Harvey, in El. Ess. II, 276/22 preasseth; James I (Arber), p. 33 preast pp.; Shakesp. Henry 8, IV, I, 77 prease.

For further examples see N.E.D.

preast, 'ready':

Respublica III, III, 5; Whetstone, Promos and Cass. III, II (N.E.D.) treaspas (verb and noun):

Tynd. Matth. VI, 12 (twice), 14, 15; lbid. XVIII, 35.

The following late ME. and early modern E. speilings also point to a long vowel in the above words.

Poems fr. Lamb. MS. 853 (E. E. T. S., Or. S. 24), 123 ff. beest: reest: breest : cheest; beest also in Trevisa, Barth. De P. R. ${ }^{\bullet} 393$ (N. E. D.); Pecock's Repressor 467/3; Past. Lett. XIX/29; Rutl. P. 70/21. - Eng. Gilds 277 geestys; Tynd. Mark XIV, 14 geest; Caxton has geest, too; see Römstedt, $l$. c., p. 8. Reest in Trevisa, Highden I, 353; Prompt, Parv. (Mayhew), col. 372; Burgh's Cato 342 (: beest 'beast'); in Caxton. see Römst, l. c., p. 8; Tynd. Matth. XII, 43; XXVI. 45; Luke XI, 24; XIII, 29. - Weest in Pecock's Repr. 254/6, in Tynd. Matth. VIII, 11; XXIV, 27; Luke XIII, 29. - Creest in Wycl, Exod. XXVIII, 23; Prompt. Parv. (Mayhew), col. 101 (4 times); lbid. col. 118. The Scotch spelling creist is used by Douglas, Aen. Prol. 128, 150. - Prees is frequent in late $M E$., and early mod. E.; many instances are found in the $N . E$. D.

It is peculiar that while modern English has beast, feast, crease, decrease, cease, decease, etc., the long vowel has not kept is ground in chest, crest, jest, press, etc.

In inquiring into the influence of $s$ and $s t$ on the quantity of preceding vowels one is confronted with some difficult problems. In Germanic words long vowels followed by st were generally shortened in ME., hence modern E. dust, rust, fist, list, mist, wrest. In some O. F. dialects, on the other hand, short vowels were lengthened before $s$ and $s t$, hence cease, decease, haste, beast, feast, coast, oust, etc., and in late ME. and early modern $\mathrm{E}$. there seems to have been a tendency to lengthen $\breve{e}$ in this position in Germanic words. The orthographic evidence adduced above, is confirmed by fairly numerous rimes. It is true, the evidence that rimes seem to afford, has generally to be made use of with great circumspection, because many ME. 'poets' do not appear to have been over particular in the choice of rime words. Still, if a given rime occurs pretty frequently, and is employed by a considerable number of 'poets', it is not altogether unjustifiable to assume that the vowels coupled in such a rime must have been very similar, if they were not quite indentical, or at any rate, that they were pronounced nearly or quite alike by some speakers at least.

The following rimes may possibly throw light on the quantity of the vowel in best, nest, rest, west. 
best rimes with

beast: Chaucer, C. T. D. 1033/4 ; Pall. on Husb. III, 470/2.

east: King Horn 1347/8; Curs. M. 2473/4; Alysaunder 315/16, 5612/3, 6374/5; Three Kings of Col. 6/8; Minor Poems Vernon MS. XXIII, 570/2; Pall. on Husb. I, 389/90; Capgrave, St. Kath. I, 541/3; Towneley Pl. XII, 437/8; Spenser, Epithal. 149/51.

feast: King Horn 807/8; Lyb. Desc. 989/90; Alys. 1097/8; 1123/4; Legends fr. Vernon MS. II, 625/6; VI, 649/50; Capgrave, St. Kath. I, 543;4; Lydgate, Temple of $\mathrm{Gl}$. 462/4; Id., Assembly of Gods, 2034/5; Id. Troy Bk. II, 5383/4; Generydes 2536/8; 6917/8; Towneley Pl. XXXII, 85/6; Vindicta Salvatoris 1379/80; Rede me, p. 36; Lyndesay, Satyre $745 / 6$; Udal, Ralph R. D., p. 11.

least: Böddeker, Spir. Songs III, 23/6; Leg. fr. Vern. MS. V, 705/6; Digby Pl. II, 342/3; St. Editha 1249/51; Partonope 5554/5; 8269/70; 11554/5; Nature 703/5; Heywood, Weather 1201/2; Udall, Ralph R. D. p. 75. (be)hest (probably with $[\varepsilon:]$ in $M E$., and even in early mod. E.; from OE. hæes): Arth. and Merl. 2197/8; 7409/10; Lydg., Troy Bk. II, 7565/6; Generydes, 4496/9; St. Editha 1602/4; Towneley Pl. XII, 436/7; York Pl. XXV, 201/3; Partonope 5022/3; Lonelich's Merlin 7513/4.

ME. mēst, 'most': Flor. and Blanch. 779/80; Böddeker, Spir. Songs XIV, $19 / 21 ;$ St. Editha 866/8.

nest rimes with

beast: Owl and N. 99/100; Respubl., Prol. 29/30.

east: Watson, Poems, p. 84.

least: Capgr. St. Kath V, 429/32; Henrysone, Fables 277/8.

rest rimes with

beast: Mor. Ode 359/60; Havel. 943/4; Alys. 5384/5; Three Kings of

Col. 315/7; Minor P. fr. Vern. MS. XXIV, 370/2; Cov. Myst. p. 23:

Burgh's Cato 340/2; Towneley Pl. XVIII, 145/7; Thercytes 273/3; $282 / 3 ; 439 / 40$.

east: Partonope 9502/3.

feast: Rich. Coer de L. 2027/8; Arth. and Merl. 9937/8; Lydg., Ass. Gods 2032/5; Maximian 199/206; Generydes 1287/8; Watson, Poems, p. 78. least: Vindicta Salv. 371/2; Maximian 199/203; Minor Poems fr. Vernon MS. XXXV, 433/4; Generydes 2536/9; Capgrave, St. Kath. V, 429/31; Heywood, Weather, 1199/1202.

west rimes with

beast: Cov. Myst., p. 23 ; Partonope $460 ; 1$.

east: Laz. 3786/7 A and B; 17021/2 A; Cantic. de Cr.568/9; Bone Flor. 1416/7; Alys. 5812/3; 6372/3; Lydg., Reson and Sens. 675/6; Pall. on Husb. I, 387/9; II, 162/4; Watson, Poems, p. 74.

least: Curs. M. 2119/20, MSS. C, G and F; Four Elements $383 / 5$.

It is worth noting that Shakespeare rimes rest with east and feast, west with east, and guest with feast; Vietor, Sh. Phon. § 26. The rime guest: feest also occurs in Thercytes $274 / 5$.

The old phonetic authorities give very little information about the pronun- 
ciation of the words in question, in fact, nest is the only one in which [ $\varepsilon$ :] is recorded. Bullokar almost consistently spells nzest, by which he means [n $\varepsilon:$ st] ; 74/13, 74/15, 77/24,77/30, 86/10, 98/4, 140/24, 140/25, 141/31, 142/1, $151 / 22$. But he has nest $41 / 29$, and further best $50 / 15$, etc., rest $47 / 32$, etc. Butler, too, records the pronunciation [n $\varepsilon$ : st], which he represents by neast 78/33 (but best, rest, wrest; see Glossary).

VII. French words that had [ $\varepsilon$ :] and [ei] in early modern English. conceave :

Tynd. Matth. I, 20; Luke I, 24, 31, 36; Coverdale, Luke I, B/20; Utopia 69, 86, 155; Surrey, Poems, l. c., p. 314; Gossip Mun. Room 105/8 1).

Further: Gosson, Sch. of $A b .68$, conceat. deceave :

Rede me 63, 68, 107; Tynd. Matth. XXII, 19; XX்IV, 4, 5; Mark XII, 24, 27; Mark XIII, 5, 22 ; Luke XXI, 8; John VII, 47; Utopia 34, 44, 85, 100, 108, 110, 111, 140; Surrey, Poems, l. c., p. 294 ; Lyly, Euphues 423 ; Shakesp., Tit. A. V, II, 36; Dekker, White Dev. III, II, 141.

Further: Rede me 22, disceatfulnes; Ibid. 78, 94 disceavable; Coverdale, Mark VII, C/5 disceate; Latimer, Seven Serm. 116, deceauable. perceave:

Rede me 23, 40, 64, 68, 94, 101; Tynd., Matth. II, 16; IX, 11: XIII, 14; XV, 12, 17; XVI 9, 11, 23; XVII, 13; XXI, 45; XXII, 18; Mark II, 8; VII, 18; XII, 28; Luke I, 22; V, 22; VI, 42; VIII, 46; XVIII, 34 ; XX, 19; John IV, 19; XI, 49; XVI, 19; XIX, 28; Coverdale, Luke I, B/14; Ascham, Tox. 14; Lever, Sermons 71; Utopia 19, 25, 50, 55, 100; Surrey, Poems, l. c., 292, 327/19, 329/9, 319/24, 330/43; Vicary, Anatomy, App. XVI, 297; Misogonus I, I, 88; I, III, 98; Googe, Egl. 65, 110; Egerton Pap. 88/231); Gossip Mun. Room 88/7a); Letter Geo.

Fleetwood 5:51).

receave:

Rede me 21 (: gleave, 'sword'); Ibid. 109; Tynd. Matth. VII, 8; X, 14, 40 (4 times), 41 (twice); XI, 14; XXI, 34; XXIII, 14, etc. (Frequent in Tynd.; there are 68 instances in the four Gospels alone); Coverdale, Mark; XI C/19; Utopia 70, 89, 141, 166; Sir Thomas More 1264 B 2); Lever, Sermons, 79, 86; Googe, Egl. 119; Puttenham, Eng. Poesie, 23; Stanyhurst, Aen. 23/14, 52/22, 68/20, 81/26, 84/2, 85/16; Horestes 500, 777, 787; Wallace, l. c. p. 176; Spenser, F. Q. II, X, LXIX (: gave: have); Harrington, El. Ess. II, 213/20; Goss. Mun. Room 14/5, 85/8 1); Alleyn Papers 73/23 1); Hensl., Diary 80/1 1).

Further: Coverdale, Mark II, B/5 receate.

There are many instances of receave in the $N$. E. D. leasure:

Tynd, Mark VI, 31; Utopia 21, 22; Sir Thomas More $777 \mathrm{H}^{3}$ );

1) Diehl, l.c., p. 174.

2) Grünzinger, l.c., p. 48.

3) Grünzinger, l.c., p. 47. 
Ascham, Tox. 110, 150; Id. Scholem. 116; Udall, Ralph R. D. 85; Mucedorus II, III, 5; Gasc. Steele Gl. 96; Edw. Third III, I, 158; Puttenham, Eng. Poesie 71; Horestes 281; Lyly, Euph. 74, 83, 189, 265, 393; Whetstone, El. Ess. I, 58/12; Harvey, El. Ess. II, 261/15; Bacon, Essays (Arber), 158 (twice); Shakesp., All's Well V, III, 33; Dekker, White Dev. V, I, 254.

There are 10 instances of leasure in the N.E.D., one of them from Milton's Par. L. X, 510, while leasurely is quoted from a work written in 1673 , and first published in 1677 .

seaze, sease, cease, ceaze, 'seize' :

Caxton, Jason 81b; (N.E.D.); Id., Recuyell II, 693 (N.E.D); Melusine LIX, 358 (N.E.D.); Skelton, Magnyf. 1554 (N.E.D.); Rede me 104 (:please); Colet's Will and Grocyn's Will 1); Lyly, Euph. 117; Oldcastle IV, III, 16; IV, III, 106; Shakesp., Rom. and J. III, III, 35; Gent of $V$, V, IV, 33; Dekker, Duch. Malfi II, V, 8.

Further there are between 45 and 50 instances of seare and its derivatives seasin, seazure, etc. in the N.E.D.

Middle and Modern English conceive, deceive, etc. are generally looked upon as having developed from Old-French stem-stressed forms, while conceave, deceave, etc. are supposed to be the English descendants of O. F. suffix-stressed forms (concevons, etc.), which became stem-stressed in English, in consequence of which $\breve{e}$ was lengthened to $\bar{\ell}$. According to the N.E.D. the varions forms of receive are connected either with $O$. F. receivre or with $O$. F. receveir. This really comes to the same thing, as receveir is a new formation, a new infinitive made from suffix-stressed forms of the paradigm.

The existence, however, of doublets like leisure - leasure; seize - seaze (seizure - seazure; seisin, saisin - seasin); demein(e), demain $(e)$ - demean(e) (noun and verb); pays, peys - pę̧s, peace; raisun, reisun - ręsun. reason; plaise $(n)$ - plęse $(n)$, please, and several others, makes a different explanation possible, These doublets prove that, in spite of the fact that $a i$ was smoothed into $[\varepsilon:]$ in Anglo-Norman, the older forms, those with $e i$, $a i$ (which, moreover, generally still existed in continental French) found their way into ME. by the side of the forms with a smoothed vowel. Thus, in the Cotton text of Cursor Mundi we find: 4939 receiud; 7746 receiue (:gleiue); 10785/6 perceiue: consaiue; 10878 conceiue; 15059 receiues; 17982 receyue; 18714 receive; 19472 receiuf; 20822 conceiued; 22077 receiue; but: 443 parceued; 1135 reseued; 1893/4 parceued: deceueid; $8625 / 6$ parceued; 16470 resaueid; 19472 receuip; 19544 receue; 22078 conceue (: receiue); 28794 receues.

That $e i$ was smoothed before $v$ is proved by the existence of the M.E. doublet glaive, gleive - glęve.

The modern pronunciation of conceive, etc. is not in accordance with the spelling; cf. convey, purvey, survey, prey, reins, feign, feint, etc. In $16^{\text {th }}$ century English $e i$ generally stands for a diphthong, as in ME.; occasionally it represents [ $:$ :] (feild, sheild, yeild, cheif, beleive, etc.), but [i:] is out of the question in $16^{\text {th }}$ century conceive, etc.

1) Diehl, l.c., p. 174. 
In the 16th, and perhaps even in the first half of the $17^{\text {th }}$ century the two spellings conceive and conceave represented two pronunciations: [kənseiv] and [kənse:v]. Bullokar probably pronounced a diphthong in receive 1 ). Butler says: "wee writ' receiv, and say raðer receav" (3.31), which proves that he knew the pronunciation with [ei]. On p. 68.20 he distinguishes between "to conceav utero, and to conceiv animo... . concipio", but on p. 59, where he transcribes the Apostles' Creed, he has, 'our Lord, which was conceived by the holy Gost . . . so that he does not keep faithfully to this distinction. - Daines, p. 10 condemns the pronunciation receave for receive, conceave for conceive as 'altogether against rule or authority.' He seems to be the last phonetic authority who refers to [ei] in conceive, etc.

As there is no evidence of any kind of the smoothing of $e i$ in conceit, deceit, recei $(p) t$ during the ME. period, the $16^{\text {th }}$ century [ $\varepsilon$ :] in these words must be owing to the analogy of conceave, etc, unless $e a$ reflects the beginning of the smoothing of the diphthong represented by $e i(a i)$, i. e. probably [æ:] This, however, is very unlikely in view of the present-day pronunciation, which must have developed from early modern [kənse $t$ ], etc.

The modern spelling of leisure seize, (and derivatives) is contrary to the pronunciation, too; the regular spelling would be leasure (cf. measure, pleasure, treasure, also with shortened [ $\varepsilon:])$, and seaze.

VIII. Words that had [ $\varepsilon:]$ and [e] in ME. and early modern E.

eleaven:

Mucedorns III, II, 11 aleauen; Harvey, in El. Ess. I, 119/26 eleaven; Id., lbid. II, 119/26, 120/10 aleavn (phonetic transcription). freat(e), 'fret':

Act 26 Hen. VIII, c. 9, freate (N. E. D.); Coverdale, Lev. XIII, freate $^{2}$ ); Sir Thomas More 704 G, freate $\left.{ }^{3}\right) ;$ Tottel's Misc. 27 and 204 freat (: to beat); 48 freat; 100 freat (:great); 81 freate (: heate); 218 freat (: eat); Ascham, Tox. 114, 118, 120, 121 (4 times) freat(e); 118, 121 (twice) freates; 121 freated; 108 freatynge; Hakluyt, Voyages 130, freat (N.E.D.); Laneham's Letter 17 freat; Cooper, Thesaurus, freatynge (Note in Cath. Ang., p. 36); Ben Jonson, Every Man in his H. III, IV 2).

In Levins, Man. Voc. freate rimes with 26 words in $[\varepsilon: t]$. geate 'get':

Sir Thomas More 39E, 90G, 14B, 28D geat(e); 12B, 216D [for]geatte 4 ); Tottel's Misc. 181 forgeat; Goss. Mun. Room 11/4 forgeatting 5); Respubl. I. I, 53 geate (:greate); but Ibid. III, VI, 21; V, IX, 14 geate (: sette); Ibid. V, X, 84 geate (:debte). Cf. Cely Papers 61/26, 61/38 geet; Ibid. 61/37 forgeet.

1) Hauck, Systematische Lautlehre Bullokars, p. 102

2) Price, Hist. Abl. p. 117 .

3) Orünzinger, l.c., p. 46.

4) Orünzinger, l.c., p. 49.

5) Diehl, l.c., p. 147. 
Further evidence of $(\varepsilon:)$ in get is given by Price, Hist. Abl.. p. 118, and p. $120 \mathrm{ff}$.

[be]heast :

Harl. Misc. III. 93 (N.E. D.); Udall, Erasm.. Par. Luke XIII, 3 (N.E. D.); Horestes 987; Misogonus II, V, 36 (: beste 'beast'); Stanyhurst, Aen. II, 64; II, 145; IV, 106; Id. Ps. I, 2, 126 (N.E.D) Lyly, Euph. 374; Chester Pl. III, 349; Spenser, F. Q. I, IV, XVIII (:beasts); III, IV, XXXI (: rest : surceast); III, VI, XXII (: beasts : feasts : creasts); VI, XII, XXIV (: beast: least), etc.; there are about a dozen more similar rimes in Spenser.

least, 'lest':

Rede me 145; Tynd., Luke XII, 58; Mark XIV, 38; Sir Thomas More 390 C, 618B 1); Lever, Sermons 119; Laneham's Letter 36, 56; Lyly Euph. 51, 55, 99, 117, 118, 119, 131, 144, 208, 215, etc.; about 40 times (the usual spelling in Euph.); Mucedorus I, I, 19; Gosson, Sch. of Ab. 53; Gasc., Steele Gl. 25, 95; Puttenham, Eng. P. 65; Edw. Third I, II, 117; III, I, 95; Two Noble Kinsm. III, I, 108; Misogonus II, V, 99; III, III, 54; Arden of Fev. I, I, 408; Nash, in El. Ess. I, $319 / 34,322 / 21,322 / 29,333 / 10,333 / 14,335 / 15$; Stanyhurst, Aen. 31/5, 39/33, 83/17, 85/20, 128/9 ; Dekker White Dev. V, III, 239.

This spelling remained in use till after the beginning of the $19^{\text {th }}$ century; see N.E.D.

leat(e), 'let' :

Respubl. V, VI, 21; V, X, 119; Lett. Lit. Men. 2/172); Hensl., Diary 177/12).

Price, l. c. pp. 167, 168 quotes leate from Bale's $K$. Johan 26, leatt from Ellis, lete from Caxton, Cely P., Gesta Rom. (ed. 1510), Ellis (three instances).

seaven :

Sir Thomas More $4943 \mathrm{~F}$ 3), Ascham, Scholem. 59; Laneham's Letter 3, 8, 43 (twice), 115; Webbe, Trauailes 28, 31, 32; Puttenham, Eng P. 85; Lyly, Euph. 272, 346; Harvey in El. Ess. 119/3, 119/26 (transcribed phonetically by seavn $119 / 26$ ); Id., l.c. II, 232/19, 232/23, 266/4; Mucedorus III, II, 66; Carew, in El. Ess. II, 279/3; Daniel, in El. Ess. II, 369/17; Stanyhurst, Aen. 23/10, 30/5; Dekker, Duch. Malfy I, I, 77; V, II, 272. seaventh :

Webbe, Disc. Eng. P. 54, 61; Laneham's Letter 9, 43; Campion, in El. Ess. II, 344/10.

seaventy :

Laneham's Letter 8; Two Noble Kinsm. V, I, 93.

Further there are more than 20 instances of seaven, etc. in the N.E.D. shead:

Rede me 148; Sir Thomas More $385 \mathrm{~F}^{3}$ ); Locrine I, II, 9; Ibid. III, Prol. 11; Auth. V., Ezech. XVI, 38.

1) Orrünzinger, l.c., p. 47.

2) Diehl, l.e., p. 147 .

3) Grünzinger, l.c., p. 49. 
According to Price, Hist. Abl., p. 170 shead occurs once in the Geneva N. T., sheading once each in Cranmer's, the Geneva, and the Reims $N . T$. Further there are 11 instances in the $N . E . D$.

A long vowel is also indicated by sheed in Tynd. Matth. XXIII, 35 (past part.!); Luke XI, 50 (past part.!), Rom. V, 5 (past part.!), by sheede in The Boy and the Mantle (Percy Fol.) 181 (inf.) and Fitzherb. Husb. \& 110 (inf.)

yeat, 'yet':

Ordinances etc. (end reign Henry VIII) in Boyle, Hist. of Hedon, p. LXXXVII; Vicary, Anatomy, App. XVI, 291; Goss. Mun. Room 10/9, 42/5, 45/101); Carew, in El. Ess. II, 289/24, 290/28. Cf. also yeet in Goss. Mun. Room 75/16 2).

To these may be added the Romance word jet, which also had $] \varepsilon$ :] and [e] in late middle and early modern English. The N.E.D. records the spellings jeet, geet, geit seven times, while ten instances are given of jeat, geat; jeatstone occurs as late as 1748 . Four more instances are found in Lyly's Euphues: pp. 64, 330 (twice), 331 ieat(e).

Further it is not impossible that many and together had [ $\varepsilon$ :] and [e] in early mod. Eng; in fact, Gill actually has $e$ and $e \cdot(=[\varepsilon:])$ in together. The following ea spellings may point to [ $\varepsilon$ :] :

Latimer, Sermon on the Pl., 25 meany; Id, Seven Serm., 40 meany; 144 meanye; Olde, Antichrist 6, meanye (N.E.D.); Becon, Display Popish Mass, Wks. III, $47 b$ meany (N.E.D.); Cf. Lyly, Lett. to Burleigh, Wks. I, 28, meinie.

Laneham's Letter 52, togeather; Vicary, Anatomy 28/7, 33/26, 61/2, 76/21, 77/29, togeather; Ibid. App. XVI, 297 togueather (but also together 28/7, 45/29, 55/28, etc); Inv. Ch. Goods in Ann. Lichfield IV, 6 to geather (N.E.D.); Horestes 1064, to geather; Arden of Fev. III, III, 42; III, IV, 127 togeather; Stanyhurst, Aen. 5/7 altogeather; $127 / 1$ al too geather.

Leper and its derivatives are spelt 8 times with ea among the examples given in the N.E.D. (to which may be added leaprosie, Dekker, Duch. Malfy III, III, 64), so that at one time (16-18 cent.) this word, too, may have been pronounced with $[\varepsilon:]$ and with [e].

IX. Romance words ending in -ede, -eed, -eme, -ete in present-day English. excead(e) :

Coverdale, Josh. I, 10; 1 Chron. XXII (XXI), 13; Ps. CIV (CV), 24;

Matth. V, B/26; Eden, Treat. New Ind. (Arber), XLI, 8, 22, 23, etc.; Kyng. Dar. 986; Spenser, F. Q. II, X, LXX (: read). $\operatorname{procead}(\mathbf{e})$ :

Tynd., Matth. IV, 4 ; Mark VII, 21 ; John XV, 26; Coverd., 1 Sam. XIX, 2; Matth. VII, C/3; Latimer, Seven Serm, 79; Tottel (Brooke), Rom. and Jul. 304; Letters Qu. El. and James VI, 74/21; Egerton Papers 483); Googe, Egl. 127; Neuyll in Googe, Egl. 23 (: spreade);

1) Diehl, l.c., p. 147.

2) Diehl; l.c., p. 148 .

3) Diehl, l.c., p. 162. 
Document in Wallace l. c., p. 168; Eden, Treat. New. Ind. XLI (twice), 57,64 , etc. succead:

Surrey, Poems in Anglia XXIX, p. 323. blaspheam:

Kyng Dar. 978, 1044.

embleam: esteam :

Francis Thynne's Embleames (Title).

Skelton, Vox Populi 672 (N.E.D.); Utopia 137; Neuyll in Googe, Egl. 21; James I (Arber) 31 (: seames, 'seems'); Slr T. Herbert, Trav. 106. extream :

Act Henry VII, C 24 (N.E. D.); Chron. Calais 112/101); Utopia 35, 37, 146; Surrey, Poems l. c., 334/12 (: dreanie); Webbe, Travailes, Title; Purit. Widow III, III, 50; Two Noble Kinsm. IV, II, 113; Lyly, Euph. 230, 328, 357, 465, 461; Harvey in El. Ess. II, 249/31, 252/27, 262/13; Nash in El. Ess. II, 241/18, 241/31; Chapman, El. Ess. II, 302/25, 307/3; Bacon, Essays (Arber), ed. 1597, 150; ed. 1607--12, 184, 186, 252, 258, 360, 378; Shakesp. Wint. T. IV, IV, 6; Timon III, II, 14;

Tit. A. III, I, 216; Dekker, Duch. Malfy III, II, 56; Id. White Dev., V, IV, 43.

The spelling extream is employed by Addison and Pope; see the N.E.D., where further instances are given, the latest dating from 1774 . supream :

Lyly, Euph. 451; Locrine IV, I, 40; Harvey, El. Ess. I, 121/21. See further the $N . E . D$., which gives a great number of examples, especially from $17^{\text {th }}$ century authors. The spelling $\operatorname{supream}(e)$ is used by Chapman, Daniel, Donne, and Milton. theam:

Latimer, Seven Serm. 22; Gascoigne, Steele Gl. 31; Googe, Pop. Kingd. IV, 44b; Harvey, El. Ess. I, 111/14; Nash, El. Ess. I, 337/22 ; Shakesp., Haml. V, I, 289; Tit. A. V, II, 80.

Further instances are found in the N.E.D. compleat:

Arden of Fev. III, III, 161; Ben Jonson, Epic. I, I, 12; Shakesp., Tr. and Cr. III, III, 181; IV, I, 27; The Compleat Gentleman; The Compleat Angler; The Compleat Englishman (titles of books by Peacham, Walton, and Defoe resp.).

The spelling compleat is used by Milton, Addison, Pope, and Johnson; see the $N . E . D$, which gives examples dating from the very end of the $18^{\text {th }}$ century (1795). repleat:

Boorde, The Boke for to lerne B IIIb (N.E.D.); King James I (Arber), p. 33 (: feat); Shakesp., All's W. II, III, 183.

1) Diehl, l.c., p. 162 
Further instances, especially from $17^{\text {th }}$ century writers, are given in the $N . E . D$.

secreat (adj. and noun):

Surrey, Poems, Angl. XXIX, 292 (4 times), 294, 311 (twice), 317, 325/25;

Sir Thomas More $\left.263 \mathrm{E}^{1}\right)$; Eden, Tr. New. Ind. etc. XLIV (4 times), 43, 51, etc,; Watson Poems 85, 100; Lyly, Euphues 1, 67, 415, 416 (3 times), 417. The $[\varepsilon:]$ in the above words, as pronounced in early modern English (in the $18^{\text {th }}$ century spellings like compleat, exteram, etc. were, of course, purely traditional) must be owing to the influence, either of contemporary or of earlier continental French.

Shakespeare rimes extreme and theme with dream and stream ${ }^{2}$ ), but the rimes in which exceed and proceed occur, point to [i:]3).

Rimes that point to $\left[\varepsilon\right.$ :] also occur in the $16^{\text {th }}$ century:

Surrey, Poems, Angl. XXIX, 334/32 extreame: dreame ( $=$ Tottel's Misc. p. 19); Tottel's Misc. p. 270 excedes : leades 3 p. s.; Watson, Poems, p. 153 blaspheme : dreame; Nature II, 25/6 kynrede : succeede; Neuyll in Googe, Egl. 23 proceade : sprede.

Secret generally has the stress on the first syllable in $16^{\text {th }}$ century poetry; still the fact that it is sometimes spelt with $e a$ in the second syllabe, and also Tyndale's spelling secreet in Mark. IV, 22 seem to point to a second pronunciation [sikrs:t] or [sakrs:t].

$X$. Words that are generally supposed to have had [e] in early modern English.

allea(d)ge in Vicary, Anatomy, App. XVI, 295; Lyly, Euphues, 64, 320, 366; Harvey in El. Ess., 265/35; Eden, l. c. 115.

bead 'bed', in Stanyhurst, Aen. 40/15; 81/4. Cf. beed in Tynd. Matth.

IX, 6; Mark II, 4, 9, 11, 12; Lake XI, 34; XVII, 37; John V, 11, 12;

Rev. II, 22; beeddes Id, Mark. VI, 55.

beager 'beggar' in Hensl., Diary 65/34).

bealie, bealye in Latimer, Seven Serm. 116; Respublica IV, IV, 104.

discreation in Lyly, Euphues 121.

eanded pret. in Hensl., Diary 256/10 4 ).

feache in Hensl. Diary 105/34).

hearing, hearinges, 'herring(s)', in Lyly, Euphues 414.

ealm in Hensl., Diary 18/114).

freasche in Respublica V, VIII, 13.

healm in Watson, Poems 121; Transl. Bullinger's Decades 1001 (N.E.D.). healp(e) in Rede me 35, 80, 101, 103, 108; Latimer, Seven Serm. 108, 135,

163; Id. Sermon on the Pl. 23, 34, 35; Lever, Sermons 119, 121, 123. mealt in Harvey, in El. Ess. II, 278/15.

sealf in Hensl. Diary. 236/2 4).

shealf in Laneham's Letter 41.

bearwhealpes in Laneham's Letter 46.

1) Grünzinger, l.c, p. 47.

2) Viëtor, Sh. Phon. pp. $15,165$.

3) Viëtor, l.c., pp. 15, 121, 122.

4) Diehl. l.c., p. 147. 
heather, 'hether'. i. e. 'hither' in Horestes 27, 127, 305, 608.

increadible in Lyly, Euphues 72.

leasson in Latimer, Seven Serm. 22.

leacher, leachery(e) in Rede me 50; Stanyhurst, Aen. 100/19, 101/18;

Dekker, Duch. Malfy III, II, 101.

leaft, adj. pret., and past p., in Laneham's Letter $4,8,21$; Letter in Wal-

lace, Evolution 153 (twice); Powel, Lloyd's Cambria 269 (N.E.D.).

Cf. leeft in Tynd., Matth. VIII, 15; XXIV, 2; Mark XII, 20; XIII, 2;

XXI, 22; Luke IV, 39; V, 28; X, 40; XX, 31 .

overwhealmethe in Surrey, Poems, Angl. XXIX, 325.

leavel in Stanyhurst, Aen. 5/6; Sidney, Apologie 55.

There are three more instances in the N.E.D.

meari, mearey in Watson, Poems 127; Horestes 334.

meashed in Tottel's Misc. 54.

preasent(e) in Latimer, Seven Serm. 52; Horestes 500, 1128.

preaty in Sir Thomas More, 502 D, 872 C 2); Udal, Erasm. Apoph. 224b

(N. E. D.). Cf. preety in Bunyan, Pilgr. Prog. II; 66.

realish in Lyly, Euphues 329.

wreake, 'reck', in Locrine II, IV, 21.

seante 'sent', in Hensl., Diary 177/1 1).

speakelation in Misogonus III, III, 16.

streache, streatch(e) in Sir Thomas More $\left.623 \mathrm{D}^{3}\right)$; Gosson, Sch. of $A b$.

57; Arden of Fev. I, 551.

teather in Latimer, Seven Serm. 51 ; Best, Farm Bks. 145 (N. E. D.);

N. Bacon, Dise. Govt. Eng. II, XXX, 137 (N. E. D.). Cf. teyther in

Nottingh. Rec. IV, 170 (N. E. D.; date 1577).

Theames in Lyly, Euph. 434.

veary(e) vearey in Horestes 121, 208; Stanyhurst, Aen. 24/13.

Several of the above spellings, especially those which only occur sporadically, are no doubt owing to the fact that in early modern English so many words had $[\varepsilon:]$ and $[e]$, so that they might be written with $e a$ or $e$, in other words, beager, bealie, discreation, eanded, hearing, feache etc. are inverted spellings. Many of them are found particularly in certain writers and texts, as Sir Thomas More, Latimer, Henslowe, Lyly, Horestes.

In theather however, ea may point to [ $\varepsilon:]$, cf. feather, heather, leather, etc., and the same holds good with regard to preaty. In leaft too, we may have ]$\varepsilon:$; the lengthening of short vowels before $f t$ may have begun as early as the $16^{\text {th }}$ century, at any rate in certain localities. The frequent spelling leeft in Tyndale is significant; Tyndale's N.T. was printed in Germany, in all probability by men who did not know English, so that leeft may be regarded as Tyndale's own spelling. But what are we to think of Tyndale's beed? And what is the meaning of $e a$ before $l$ (in $e a l m$, healm, healp, etc.)? Can the $a$ have been introduced here to represent the low-pitched, $a$-like glide between $e$ and $l$ ?

1) Diehl, l.c., p. 147.

2) Grünzinger, l.c., p. 49.

3) Grünzinger, l.c., p. 50. 
XI. Words that had $\underset{e}{e}$ in ME. i. e. Anglo Norman $\bar{e}$, or $\bar{e}$ from OE. $\bar{a}, \bar{e} o$. agreamentes in Document in Wallace, l. c. p. 176.

beach in Lyly, Euphues. p. 43.

betael, 'beetle' in Latimer, Seven Serm. 90.

to bread: Misogonus II, I, 26, to breade; Ibid. II, II, 109 breadlings,

Googe, Egl. 126, to bread; Watson, Poems p. 99, breades, 3. p.s.

to creap: Surrey, Poems, Angl. XXIX 333/40 creapes; Utopia 161 creapeth. deame 'deem' in Rede me 177.

deape in Utopia 78; Misogonus II, V, 140 (: wepe, inf.).

to fead: Tynd. Luke VIII, 32 feadynge; Latimer, Seven Serm. 49 feadeth;

Surrey, Poems l. c. 306/30; 307/70; 312/13 (: seeade, 'seed') fead(e);

Googe, Egl. 41 to feade (: seade, 'seed'); Ibid. 109 to feade; Hulvet,

Feade fatte . . . Feade full (N. E. D.).

to feal(e): Morte Darth. 360/29 I feale; Surrey, Poems, l. c. 291/50 feale

(: weale); 313/30 feale; Utopia 122 fealing sub.; Respublica III, I, 4 feale; Googe, Egl. 47, feale (: wheale, 'wheel'); Ibid. 54, 57, 62 feale; Misog. III, I, 216 to feale. Feel, fele rimes with dele, deale Misog. I, I, $139 ;$ I, II, 64.

fealdes in Ascham, Tox. 98.

feate, 'feet' in Rede me 33; Surrey, Poems, l. c., 313/44.

flea (verb.) in Dekker, Duch. Malfy V, II. 80.

greaf: Ascham, Scholem. 36 greafe; Gossip fr. Muniment Room 20/14 greave1).

Greake in Harvey, El. Ess. I, 123/6.

greasyn, 'Grecian' in Hensl., Diary 48/11 t).

heade 'heed' in Ascham, Tox. 101;

to keap(e): Chelmsford Churchwardens' Accts. 1562-'3 in Chambers, Med. Stage II 346, keapinge; Letter in Wallace, l. c. 131 keaps; Ordinances end reign Henry XIII, in Boyle, Hist. . . of Hedon pp. LXIX, LXXIII, LXXVII, LXXIX (3 times), keape; Ibid. XCV keapes; Ibid. LXXVII, keaper; Ibid. LXX keapid; Ibid. LXXXVI keapt; Ibid. LXIX, LXXX (3 times) keaping e); Misog. IV, III, 52 keape; Respublica I, IV, 37; V, IX, 136, keape; Blunderton, in Googe Egl. 27 keape, keaping; Hensl., Diary 80/4, keaping ${ }^{1}$ ).

leage, 'liege' in Vicary, Anatomy, App. III, 175.

lear(e), 'leer': Morte Darthur 371/4 learys; Gascoigne, Compl. Phil. 106 leare (: cheere).

to lease 'lose' : Ordinances, etc. in Boyle, Hist. of Hedon, LXX, LXXIII, LXXX, XCIV (twice) lease; Ascham, Tox. 100, 117, lease; Id., Scholem. 58 lease; Misog. III, I, 123 to lease (: seas, pl. of 'sea').

leaver, 'liefer', in Sir Thomas More 985 E, 1085 C 2). to meat: Ascham, Tox. 53, 89 meatinge(s); Utopia 45 meatynge. meate adj. in Vicary, Anatomy, App. III, 177. peace, 'piece, in Sir Thomas More $388 \mathrm{E} 3$ ).

1) Diehl, l.c., p. 162.

2) Grünzinger, l.c., p. 40.

3) Grünzinger, $l c$, p. 39. 
peaple, 'people', in Alleyn Mem. 28/22 1).

preastes, 'priests' in Rede me 163 (twice); Coverdale, Luke XXIII, B/26.

reaking, 'reeking' in Edw. Third III, V, 90.

sea 'the see of Rome' in Latimer, Seven Serm. 189.

seage in Hensl. Diary, 97/16 1).

to sea in Shakesp., Mids. III, II, 232; John III, I, 144; V, II, 72; Henry

Fourth B IV, I, 42.

seack, 'sick', in Alleyn Mem. 28/27 2).

to seak(e): Googe, Egl. 35 seake; 101 seakest; Letters Qu. El. and James

VI $78 / 20$, beseach 1$)$.

to seam: Vicary, Anatomy, App. III, 151 seame; Surrey, Poems, Anglia

307/65 seamd; Ibid. 308 seamed; Letters Qu. El. and James Vl 27/3,

seameth 1). Googe, Egl. 54 seamd; Ibid. 108 seamed; James I (Arber),

p. 31 seames (: esteames); lbid. 33 seame (: dreame).

sleavfe, 'sleeve' in Hensl. Diary 105/251).

speade: Vicary, Anatomy, App. III, 177 speade; Webbe, Trauailes pp. 18,

25 speadely; Lyly, Euphues, 92 speadely; Ibid. 446 speade.

spleanes in Carew, El. Ess. II, 296/13.

squease in Respublica V, X, 93.

teamed, 'teemed', in Stanyhurst, Aen. 87/26; Shakesp. Haml. II, II, 531.

theaff in Respublica V, IX, 150.

weake 'week', Misog. III, I, 8 weake; Hensl. Diary, 55/14, weacke 1).

weant, 'weened', in Sir Thomas More, $918 \mathrm{~F}$ 3).

wheal(e): Respubl. I, I, 9 wheale; Googe, Egl. 47 wheale (: feale); Ibid.

52 wheale; Stanyhurst, Aen. 22/18, wheales; Writing Scholar's Comp.

$114 / 2$ wheal.

yeald: Sir Thomas More $215 \mathrm{H}_{\text {, gealdyng }}{ }^{3}$; Laneham's Letter 42 yeald;

Googe, Egl. 98 yealded; Ibid. 118 yealding; Document in Wallace, l. c.,

p. 176 yeald, yealded; Carew, El. Ess. II, 291/14, yealded; Egerton

Papers 98/21, and Gossip fr. Mun. Room 43/4, 62/5 yeald ${ }^{1}$ ).

Although at first sight these spellings seem puzzling, it is not impossible to account for them. Just as $e a$ for [e] is probably an inverted spelling, ea may stand for [i:] through inversion. In many words both $e e$ and $e a$ were legitimate, either because these words had two forms in ME., one with $\bar{e}$ and the other with $\bar{e}$ (deed - dead, street - streat, meel - meal, and many others), or because ME. $\bar{e}$ developed into [i:] and [s:] cheer - chear, deer - dear, heer - hear, etc). People saw words they pronounced with $[i:]$ themselves, spelt with $e a$ (because other people pronounced [ $s:]$ ), and this may have led them to employ $e a$ in words that they, and everybody else, pronounced with [i:] (feel - feal, keep - keap etc).

There may, however, be another reason for the use of $e a$ in the words in question. There are quite a number of Midland and Southern dialects in which words that had $\bar{e}$ in ME. still have [e:] at the present time; see Wright, Dial. Gr. $\$ \S 142,145,220$. Although there is no evidence as to the

1) Diehl, l.c., p. 162

2). Diehl, l.c., p. 163

3) Grünzinger, $t$. c. p. 40. 
pronunciation of such words in early modern English, we cannot go far wrong if we assume that the [e:] in them has remained practically unchanged since the ME. period. The $e a$ in feal, keap, etc. may, therefore, sometimes if not always, have been meant to represent [e:].

The above remarks need not be applied to the spelling nead, which occasionally occurs in $16^{\text {th }}$ century English. The $e a$ may represent the $[\varepsilon$ :] sound here; this $[\varepsilon:]$ may have arisen from $\mathrm{OE} . \bar{e} a$ in nead, neade, neadian, while need with [i:] is probably the descendant of $\mathrm{OE}$ ned, nēod, nēele, nédan, nēodian; as is well-known, confusion as regards these forms already arose in $\mathrm{OE}$. The examples of nead etc. that have been found so far are:

Tynd., Matth. VI, 8; VI, 32; IX, 12; XIV, 16; XXI, 3 neade (noun and verb); Rev. XVI, 2 neadeth; ordinances in Boyle, Hist. of Hedon LXXIV neadfull; Latimer Seven Serm. 155 neade, sub.; Ascham, Tox. 81 neades, adv.: Ibid. 84 neaded; Utopia 61, 83, 141 neade, (sub.); Ibid. 99 neades adv.; Cranmer's Bible, Ps. X, 1 neadefull (N.E. D.); Kyng Daryus 177 neades adv., Aurelio and Isab. G VI neade (sub) (N. E. D.). The form feable, which is occasionally found (in Sir Thomas More, Grünz. l. c. p. 39 ; Utopia 57 ; see further the N.E.D.) probably does not represent [fi:bl], but [f: bl], the $[\varepsilon:]$ being the result of the smoothing of $e i>\bar{\varepsilon}$ in feible, which existed in OF. by the side of feble. This feible, in its later form, was subsequently introduced into English for the second time as foible.

In conclusion I will adduce a few spellings that throw - or at any rate may throw - light upon 16th century pronunciation.

The spelling eau (eaw), which is not infrequent in early modern English is only found as the representative of one of the two diphthongs denoted by eu (ew), namely the one descended from OE. zew and éaw (> ME $\bar{e} u$ ). Some writers evidently thought it advisable not always to represent $[\varepsilon: u]$ and $[i: u]$ by the same symbol. It is worth noting that $16^{\text {th }}$ century [i:u] $<$ ME e u does not appear ever to be spelt eau.

The eau spelling is found in:

deaw: Tusser, Husb. 91 (N.E.D); Lyly, Euphues 235, 236; Greene, Menaphon (Arber), 27, 74 ; Nash, El. Ess. I, 308/8; Spenser, F. Q. V, I, 36; I, V, 2, etc. (occurs frequently).

feaw(est): Rede me 40, 87; Tyndale, Matth. VII, 14; IX, 37; XV, 34; $\mathrm{XX}, 16$; Mark VI, 5; Lake XIII, 23; Coverdale, Rev. II, C/28; Laneham's Letter, 1, 18, 24, 56.

heaw(en): Tyndale, Luke XXIII, 53; Laneham's Letter 50, 52; Sylvester, Du Bartas II, III, I, 313 (N.E.D.)

leaud, leawd (-ness; -ly): Rede me 55, 68, 115; Tynd. Rom. I, 28; 2 Tim. III, 8; H. Smtth, Serm. 568 (N. E. D.); Golding, Heminges Post., Ded. 2 (N.E.D); Purchas, Pilgrimage 321 (N.E.D); Lyly, Euphues $44,46,60$.

meaw : Capt. Smith, Virginia VI, 216.

sheaw(ed): Rede me, 88; Laneham's Letter 1, 18, 20, 33, 34, 39, 54, 56; Tusser, Husb. 92 (N.E. D.). streawd: Laneham's Letter, 8. 
Occasionally $e a$ is found for ME. $a i$, $e i$; this $e a$ probably symbolizes the smoothing of $a i$, ei, resulting in its coalescence with the $16^{\text {th }}$ century representative of ME. $\bar{a}$, which latter sound is also occasionally, though very rarely, indicated by $e a$. The examples I can give, are :

ai > [æ:]. ail: Misogonus I, I, 202 ealeth, 3 p. s.

braid: Spenser, $F$. Q. III, II, XV; III, II, L breaded.

complain: Plampton Corr. 80/18 compleane ${ }^{1}$ ).

disclaim: Goss. fr. Mun. Room. 101/10, discleame ${ }^{1}$ ).

despair: Tynd. Pref. 10, despeare.

fair adj.: Stanyhurst, Aen. 24/29, feare.

flay: Dekker, Duch. Malfy II, I, 36 flead.

layer: Egert. Papers 348/6 brickeleaers 1),

to play: Chester Procl. for the Plaies, Chambers l. c. II, 340, plead pp. praise: Ascham, Scholem. 55 preasing.

prey: Surrey, Poems, Angl. XXIX, 330/26, prea.

railings: Tynd., 1 Tim. VI, 4 realings.

raise: Latimer, Seven Serm. 208, rentreaser.

remain: Goss. fr. Mun. Room 17/8, remeane.

to stay: Horestes 451 stease, 3. p.s.

their: Horestes 212, 319, 325, 329 thear; same spelling in Stanyhurst,

Aen. 75/9; Bacon, Essays (Arber), 372.

$\bar{a}>$ [æ:] grace: Respublica II, III, 14 greace.

made: Gascoigne, Steele Gl. 29, meade (:stead).

share: Alleyn Papers 19/18; Hensl. Diary 102/5 sheare ${ }^{2}$ ).

Further: Hensl. Diary, 101/25, Arceadian; 69/13 Jeames ${ }^{2}$.

In this connection the following rimes, found in Markham, Grenville (Arber), are interesting:

p. 78 . eares: swears, displairs, p. 79 , faith: death; p. 80 , sea: lay: stray;

p. 83 she beares: feares : repaires; p. 85 , eares: despaires : teares.

$E a$ for the first element of the diphthong that had developed from ME. $\vec{l}_{\text {, }}$ is rare; I have only found eayre, 'ire', in Horestes 670, and 904 (: fyare, 'fire').

This trigraph also occurs in Kyng Daryus in feayre, 'fair', 1. 55, sleaye 'slay' (: awaye), 1. 105, and to sleay 'slay', 1. 1316. Query: what does this curious spelling mean here? Does it stand for [zi]?

Amsterdam.

W. VAN DER GAAF.

\section{THE ARTICLE BEFORE SUPERLATIVES.}

§ 1. Before a Predicative or an Adverbial superlative there is commonly no Article. But all grammarians who have written about the subject: Mätzner, Koch, Schmidt, Wendt, Poutsma, are agreed in admitting that to this rule there are a great many exceptions. Indeed, even in Shakespeare ${ }^{3}$ ) we find

1) Diehl, l.c., p. 174 .

2) Diehl, lc., p 160.

3) Frantz, Shakespeare Grammatik 2, § 267 Anm. 